\title{
Predicting transmission of pulmonary tuberculosis in Daerah Istimewa Yogyakarta Province, Indonesia
}

\author{
Al Asyary, ${ }^{1}$ Aries Prasetyo, ${ }^{2}$ Tris Eryando, ${ }^{3}$ Yodi Mahendradhata ${ }^{4}$ \\ ${ }^{1}$ Department of Environmental Health, Faculty of Public Health, Universitas Indonesia, Depok; ${ }^{2}$ Study \\ Program of Environmental Health, Health Polytechnic of Surabaya, Ministry of Health, Magetan; \\ ${ }^{3}$ Department of Biostatistics and Population Studies, Faculty of Public Health, University of Indonesia, Depok; \\ ${ }^{4}$ Department of Health Policy and Management, Faculty of Medicine, Public Health and Nursing, \\ Universitas Gadjah Mada, Yogyakarta, Indonesia
}

\author{
Correspondence: Al Asyary, Department of Environmental Health, \\ Faculty of Public Health Universitas Indonesia, Gedung C Lt. 2 \\ Kampus FKM-UI Depok, Jawa Barat, Indonesia, 16424. \\ Tel./Fax: +62.21.7863479. \\ E-mail: al.asyary13@gmail.com
}

Key words: Spatial analysis; Tuberculosis; Infectious disease; Epidemiology; Daerah Istimewa Yogyakarta Province; Indonesia.

See online Appendix for additional material.

Acknowledgements: the authors thank to several parties which consisted of: University of Indonesia (UI), MoH of Health Polytechnic of Surabaya - Magetan, and Universitas Gadjah Mada (UGM). We would like also thanks to all of our contributors: Dr. Carol Clark and Prof. Edwin van Teijlingen - Bournemouth Unversity; TB Surveillance Unit of Yogyakarta Health Offices (Wasor TB Dinkes Kab/Kota dan Provinsi: Mr. Achmad MD MPH, Mrs. Boni MD MPH, and Mr. Ugik MPH - Provincial; Mr. Sudio MPH - Sleman; Mrs. Ira MPH - Kulon Progo; Mr. Mus MPH - Gunung Kidul; and Mr. Oki MD - Bantul), The KNCV of Yogyakarta (Mr. Alex MD), and field enumerators (Ms. Heni DipSc, Ms. Enie DipSc, Ms. Ari DipSc, Ms. Feni DipSc, Ms. Tri DipSc, and Ms. Chandra DipSc).

Contributions: AA planned and conducted the study and wrote the first draft of the manuscript; AP analysed the findings report; TE and YM were both involved in the critical revision of the report and manuscript.

Conflict of interest: the authors declare no potential conflict of interest.

Funding: this study was sponsored by the University of Indonesia and supported by CSR ANTAM Co.Ltd. Scholarship.

Ethical statement: informed consent from the respondent was obtained in written form. Ethic approval of the study was obtained from the Expert Commission on Research and Research Ethics of Public Health Faculty, University of Indonesia, Number: 87 /H2.F10/PPM.00.02/ 2014.

Received for publication: 24 January 2018

Revision received: 26 November 2018.

Accepted for publication: 26 November 2018.

(C) Copyright A. Asyary et al., 2019

Licensee PAGEPress, Italy

Geospatial Health 2019; 14:673

doi:10.4081/gh.2019.673

This article is distributed under the terms of the Creative Commons Attribution Noncommercial License (CC BY-NC 4.0) which permits any noncommercial use, distribution, and reproduction in any medium, provided the original author(s) and source are credited.

\begin{abstract}
This study aims to explain the current dispersion of tuberculosis (TB) and provide evidence that could help predicting its future transmission in Daerah Istimewa Yogyakarta (DIY) Province, Java Island, Indonesia. One hundred thirty-two adult ( $>14$ years old) individuals, with TB diagnosed by health professionals using the Directly Observed Treatment, Short Course strategy, were identified Their residential addresses and geographical patterns of movement were investigated by global positioning systems and descriptive spatial analysis using standard deviation ellipse analysis and kernel estimation. The dispersion of TB cases was studied by ellipse regression, which showed a pattern extending in a direction oriented from north-west to south-east centred on Kasihan District, Bantul Regency, DIY Province, located near Yogyakarta City. Levels of TB risk in the study area varied from non-existent to high as calculated by kernel estimation. We conclude that suburban communities, followed by densely populated residential areas, enabled by socio-economic factors, are more likely to see increased TB transmission in the future.
\end{abstract}

\section{Introduction}

About 170 years ago, the first spatial analysis was put into practice in London by John Snow (the father of epidemiology) when he applied his then new idea to demonstrate the distribution of communicable incidents, in this case cholera. Although Snow was able to end the cholera epidemic by convincing the authorities to close the now famous Broad Street water pump, the next steps are not always revealed in epidemiological research. As with cholera, eliminating tuberculosis (TB) transmission in a population is the key and that can be effectuated by treatment before the disease spreads further. Pulmonary TB is completely curable through short-course chemotherapy, commonly with isoniazid and rifampicin, delivered through a system of checks and balances referred to as Directly Observed Treatment Short Course (DOTS), a strategy endorsed by the World Health Organization (WHO). Spatial methods have been demonstrated to contribute to the description and overview of prevalence as well as incidence of TB (Feske et al., 2011; Terlikbayeva et al., 2012). Buffer analysis can be used to explain how far the areal diameter of an area characterized by TB infections has an impact (Zendejas-Martinez et al., 2008; Jacob et al., 2010), while an analysis of spatiotemporal transmission and socio-climatic factors related to TB provide determi- 
nants that might help in predicting the likelihood of TB presence (Alene et al., 2017). However, neither of these methods can explain what happens next, neither measurement of its dispersal potential nor its assumed future transmission. However, standard deviation (SD), a statistic parameter for the mean of data dispersion, can be used to evaluate frequency histograms that would show whether the distribution is skewed in any way, whereas the mean of a SD ellipse (SDE) can be generalized to reveal central tendencies of aggregation, while the dimension of dispersion indicates the trend of distribution in spatial analysis (Lai et al., 2009). Even though the nature of the contagion (e.g., the cholera bacterium) was unknown at the time of John Snow, the source of contamination was discovered through mapping the spatial distribution of cholera cases (Panaeth, 2004). This method is currently illustrated as dispersion and prediction analysis. Although TB is not transmitted by water like cholera, the same diffusion pattern applies as it is affected by a single factor (Raviglione et al., 1995). Some studies reflect the importance of providing real-world perception according to prior TB transmission geographically (Lai et al., 2009; Feske et al., 2011; Lin et al., 2011). It is most essential to find evidence of what happens with regard to dispersion of TB compared to the prior distribution and transmission potential (Khan, 1986). This spatial study attempts to describe how progress of TB transmission might occur, particularly in the Daerah Istimewa Yogyakarta (DIY) Province of Indonesia, a lowto middle-income country.

\section{Materials and Methods}

In an effort to provide valuable information about how each coordinate setting under investigation, its importance and urgency in relation to TB epidemiology, we specified the problem by gradation of grid cell illustration. The sum of grid cell value reflected the colour pattern, generated by each quadrant that corresponds to, that showed the magnitude information of the spatial problem by its darkness colour pattern, using the interpolation method, as a kind of thematic mapping. The interpolation function, based on quadrant measurements and summation of grid cells (Rollemberg et al., 2015) becomes shaped by respondent coordinates explaining the risk of transmission among a population. The number of grid cells is based on the number of georeferenced cases determined by observational statistics, which are generalized by $\chi^{2}$ goodness of fit (Kang et al., 2016). The resulting variation of interval density is also known as kernel density estimation (KDE) (Lai et al., 2009). However, this approach has not yet demonstrated its utility, neither for public health prevention nor for infectious disease epidemiology, particularly not in the field of TB control and mitigation.

\section{Study area}

This is a descriptive study accounting for TB cases in DIY Province of Indonesia (Figure 1), which consists of five regencies

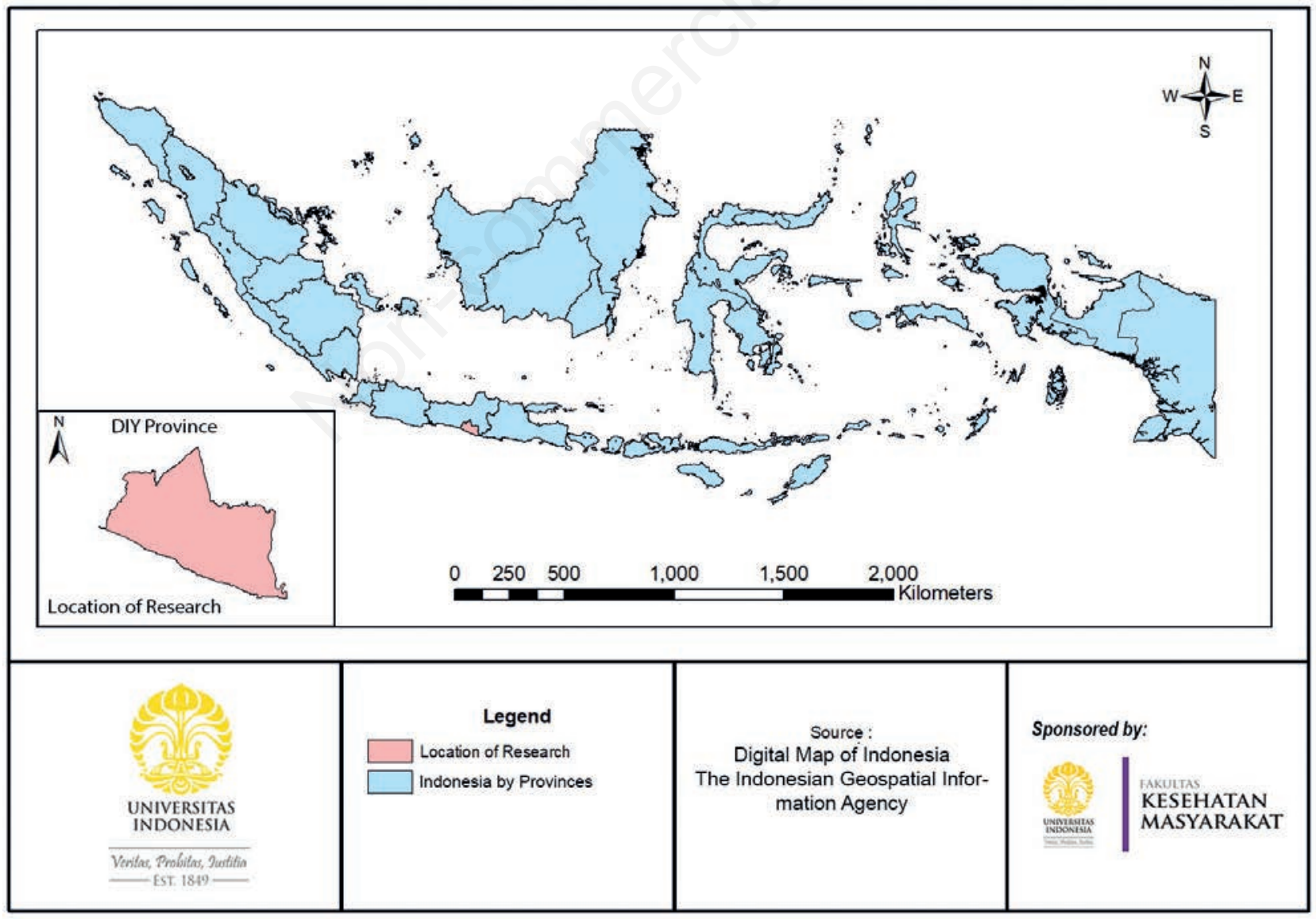

Figure 1. Map of Indonesia with the study location (Daerah Istimewa Yogyakarta, DIY) Province marked. 
with Yogyakarta as the only urban area. Yogyakarta is bordered by Sleman and Bantul Regencies whose populations have grown making them suburban areas. As can be seen in Figure 1, Sleman, Kulon Progo and Gunung Kidul border Jawa Tengah Province, while only the two latter regencies have contact with the sea. DIY Province consists of varying altitude and demography contours. Gunung Kidul Regency, for example, has a high altitude in the north with comparatively little population and a coastal territory in the south where most people live (BPS-DIY, 2014).

\section{Patient data}

The study included 132 cases ( $>14$ years old) from all five regencies of DIY Province. The respondents were cases with smear-positive TB recorded at facilities in the province capable of handling patients according to the DOTS strategy. They came from 15 primary health centres (Puskesmas) and eight hospitals. Due to limitations of data recording, this research did not include smearpositive TB cases who had been treated at other health facilities or who had no access to facilities with DOTS capability.

\section{Instrumentation}

The places where the TB cases were located were traced and recorded by Global Positioning Systems (GPS) using a Garmin 76 series instrument to define the latitude and longitude coordinates of the patients' homes. Locations and elevations were produced with a accuracy less than 10 meters.

\section{Analysis}

Spatial analysis measured geographical patterns and consisted of SDE and KDE analysis. The SDE, introduced by Lefever
(1926), is a procedure to first determine the mean areal centre of the point set collected and define this as the origin of a new set of axes for the distribution. The SD statistic, giving the orthogonal to each axis plotted as a vector originating at the mean areal centre (Yuill, 1971), was then calculated. The usefulness of SDE lies in the fact that it is capable of handling fragmented and distorted point distributions reflecting changes in the pattern of the distributions (Khan, 1986). Meanwhile, KDE provides a hotspot non-parametric estimate of the probability density function from which a set of data can be drawn (Cranmer, 2001). It was generated by CrimeStat III Statistical Software (https://www.icpsr.umich. edu/CrimeStat/) and presented with Quantum GIS 1.6.0 Copiapo (https://www.shouldiremoveit.com/Quantum-GIS-Copiapo18827-program.aspx) in order to predict the distribution pattern of TB transmission. See online Appendix for additional data.

\section{Results}

As shown in Table 1, the subjects of this study were distributed among five regencies, including Yogyakarta, the one city in DIY Province. Most adult TB cases were found in Gunung Kidul (34.8\%), and the least in Kulon Progo (7.6\%). At the district level, adult TB mostly occurred in Semin District of Gunung Kidul Regency (9.1\%) and Kasihan District of Bantul Regency (9.1\%).

During the January-December period of 2014, the location of the homes of those recorded as having a positive TB diagnosis, 132 in all. They were shown by GPS to be distributed among 33 districts of the five regencies (Figure 2). Since the Indonesian Government realized that the DOTS strategy should be improved

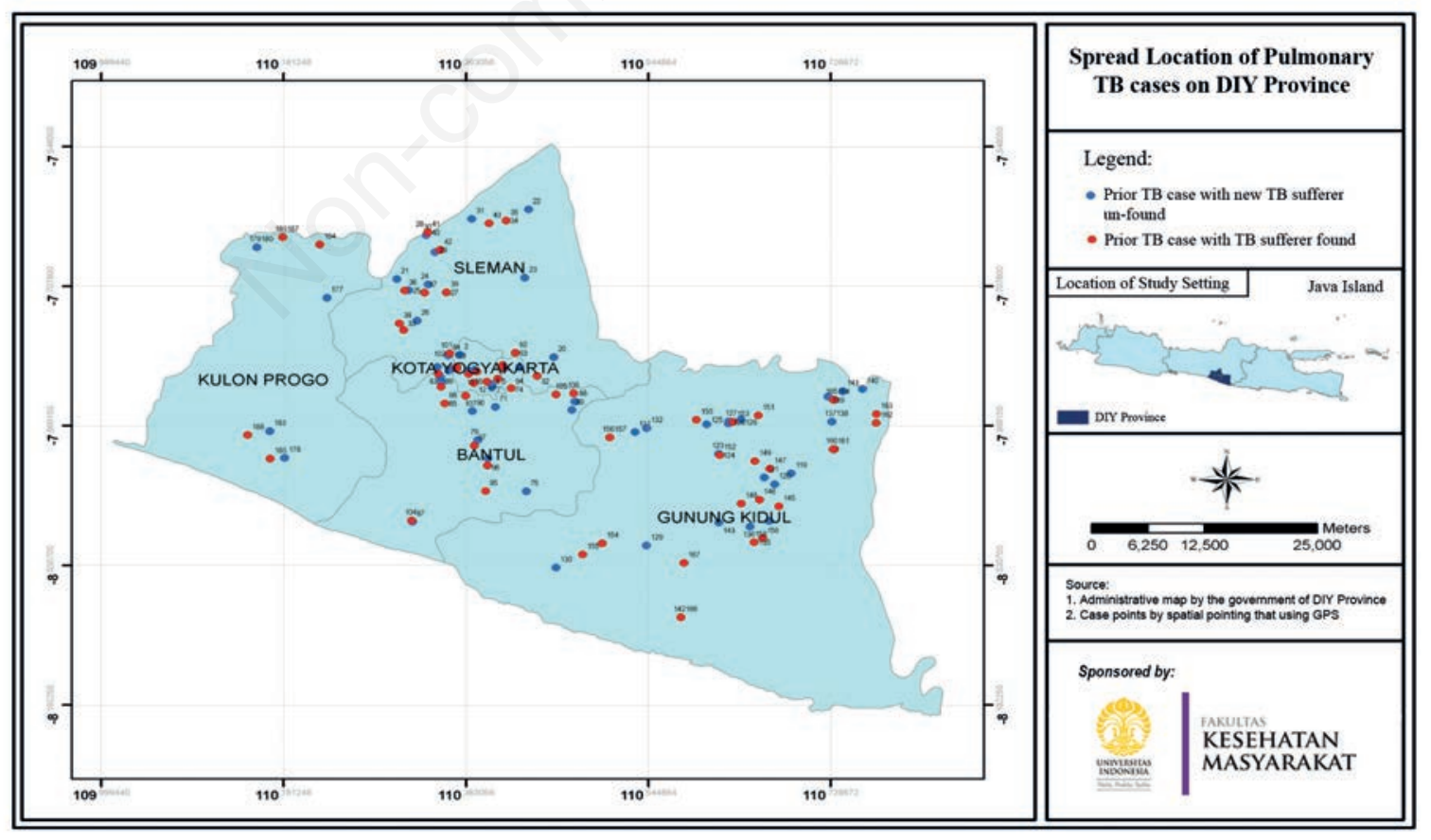

Figure 2. Current residential spread of pulmonary tuberculosis (TB) in Daerah Istimewa Yogyakarta (DIY) Province, Indonesia. GPS, global positioning systems. 
(Asyary, 2017), a new strategy was activated along with a contacttracing approach to find all suspected of TB infection, i.e. those who had been in contact with diagnosed TB cases in the Province, particularly in households (the household-contacts). When a person with TB has visited a home, the health centres (Puskesmas) have the obligation to establish and register all in that home diagnostically, either with sputum assessment (those above 14 years old) or a scoring system (for children $\leq 14$ years old). Inspecting the data registers in the different districts, we found 66 householdcontacts diagnosed with TB (found TB cases - red dots on the map) and 66 household-contacts that were not infected (unfound TB cases - blue dots on the map).

As seen in Figure 3 the dispersion of new TB cases could be predicted by a single significant ellipse regression showing a pattern extending from north-west to south-east with a central tendency of aggregation in Kasihan District in Bantul Regency that borders Yogyakarta City.

The KDE analysis estimated a series of cut-off point determin- ing the different risk level in DIY Province. The following indices were used: i) $0.012342-0.016132=$ non-existent risk; ii) $0.016133-0.018965=$ low risk; iii) $0.018966-0.022127=$ fair risk; iv) $0.022128-0.025837=$ higher risk; and v) $0.025838-0.030202=$ highest risk. This estimation resulted in evidence that the TB transmission was observed to have dispersed following two main directions. Yogyakarta City with most of the districts in Sleman Regency now showing the highest TB risk (Figure 4).

\section{Discussion}

TB dispersion was found to be more likely to occur in Yogyakarta and districts belonging to Sleman Regency, areas known to include places where people commonly gather together enabling TB transmission to occur. Yogyakarta is the heart of DIY Province and famous for its culture and other attractions that not

Table 1. Prevalence of tuberculosis (TB) in Daerah Istimewa Yogyakarta (DIY) Province by regency and district.

\begin{tabular}{|c|c|c|c|c|c|c|}
\hline Regency or city & Area $\left(\mathrm{km}^{2}\right)$ & Population overall & Density (per $\mathrm{km}^{2}$ ) & District & & \\
\hline & & & & & $\mathbf{N}$ & $\%$ \\
\hline Kulon Progo & 586.27 & 412,198 & 703 & & 10 & 7.6 \\
\hline & & & & Kalibawang & 2 & 1.5 \\
\hline & & & & Panjatan & 2 & 1.5 \\
\hline & & & & Samigaluh & 4 & 3 \\
\hline & & & & Wates & 2 & 1.5 \\
\hline Bantul & 506.85 & 971,511 & 1917 & & 34 & 25.8 \\
\hline & & & & Banguntapan & 8 & 6.1 \\
\hline & & & & Imogiri & 4 & 3 \\
\hline & & & & Jetis & 2 & 1.5 \\
\hline & & & & Kasihan & 12 & 9.1 \\
\hline & & & & Kretek & 2 & 1.5 \\
\hline & & & & Piyungan & 4 & 3 \\
\hline & & & & Sewon & 2 & 1.5 \\
\hline Gunung Kidul & 1485.36 & 715,282 & 482 & & 46 & 34.8 \\
\hline & & & & Karangmojo & 8 & 6.1 \\
\hline & & & & Nglipar & 10 & 7.6 \\
\hline & & & & Paliyan & 2 & 1.5 \\
\hline & & & & Panggang & 2 & 1.5 \\
\hline & & & & Patuk & 4 & 3 \\
\hline & & & & Semanu & 4 & 3 \\
\hline & & & & Semin & 12 & 9.1 \\
\hline & & & & Tanjungsari & 2 & 1.5 \\
\hline & & & & Wonosari & 2 & 1.5 \\
\hline Sleman & 574.82 & $1,167,481$ & 2031 & & 24 & 18.2 \\
\hline & & & & Berbah & 2 & 1.5 \\
\hline & & & & Godean & 2 & 1.5 \\
\hline & & & & Pakem & 4 & 3 \\
\hline & & & & Seyegan & 6 & 4.5 \\
\hline & & & & Sleman & 2 & 1.5 \\
\hline & & & & Tempel & 6 & 4.5 \\
\hline & & & & Turi & 2 & 1.5 \\
\hline Yogyakarta & 32.5 & 412,704 & 12,699 & & 18 & 13.6 \\
\hline & & & & Gondomanan & 2 & 1.5 \\
\hline & & & & Jetis & 2 & 1.5 \\
\hline & & & & Kota Gede & 4 & 3 \\
\hline & & & & Kraton & 2 & 1.5 \\
\hline & & & & Umbulharjo & 4 & 3 \\
\hline & & & & Wirobrajan & 2 & 1.5 \\
\hline Total in DIY Proving & & & & & 132 & 100 \\
\hline
\end{tabular}


only draw people around Indonesia to study but also is a tourist focus (Smithies, 1986). Meanwhile, Sleman Regency has become a supporting area for Yogyakarta as it has already long been a destination for people looking for a flat as domicile or rooms to rent at boarding houses (Giyarsih, 2010). TB has a strong potential to disperse along these areas as both Sleman and the city, for reasons mentioned above, have greater migration flows than other districts.

The results show that the incidence of TB cases in DIY Province was not equally distributed throughout the five regencies/municipalities. Instead, the cases were more concentrated in

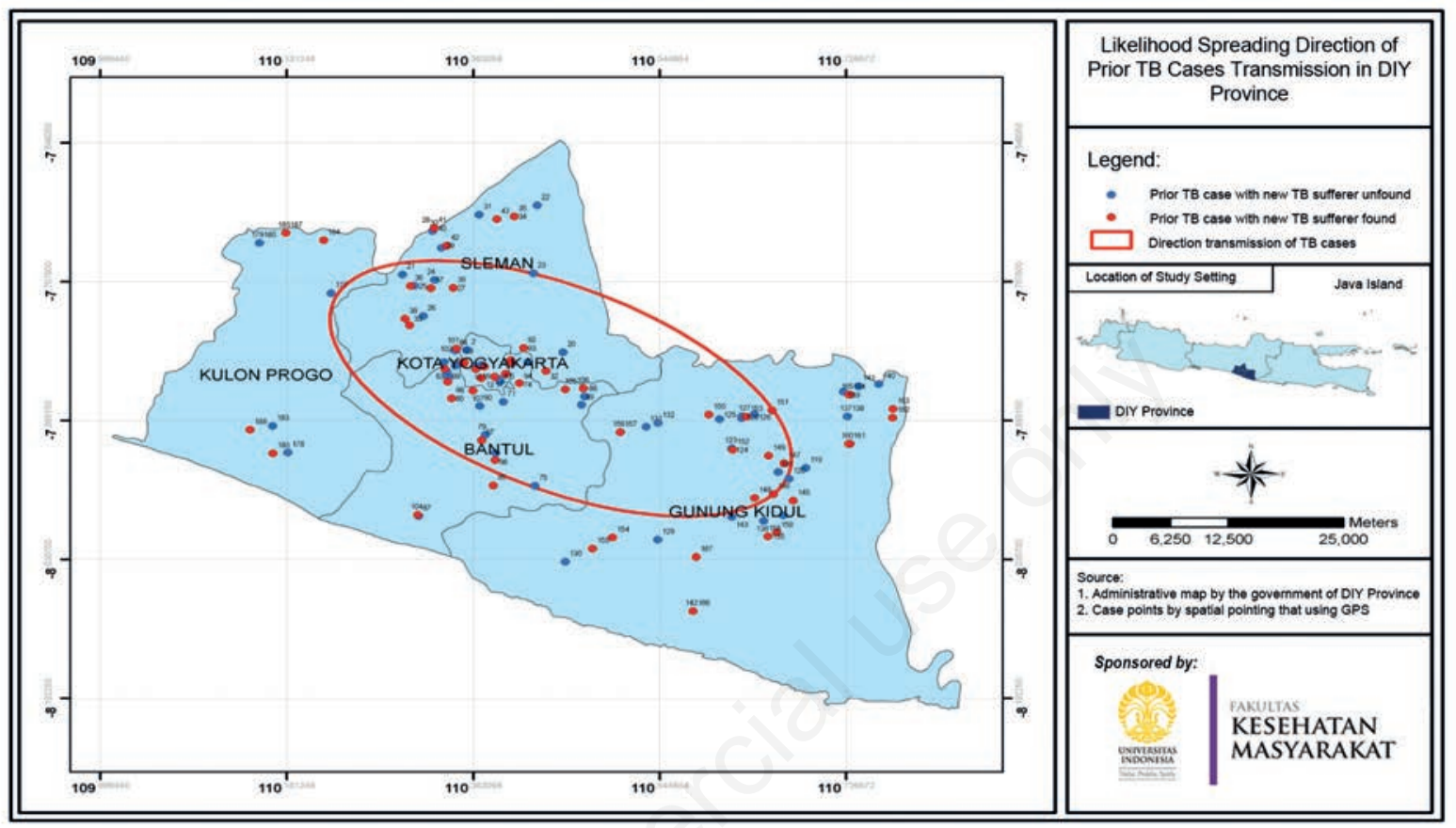

Figure 3. Likelihood of tuberculosis (TB) transmission from prior TB cases in Daerah Istimewa Yogyakarta (DIY) Province, Indonesia.

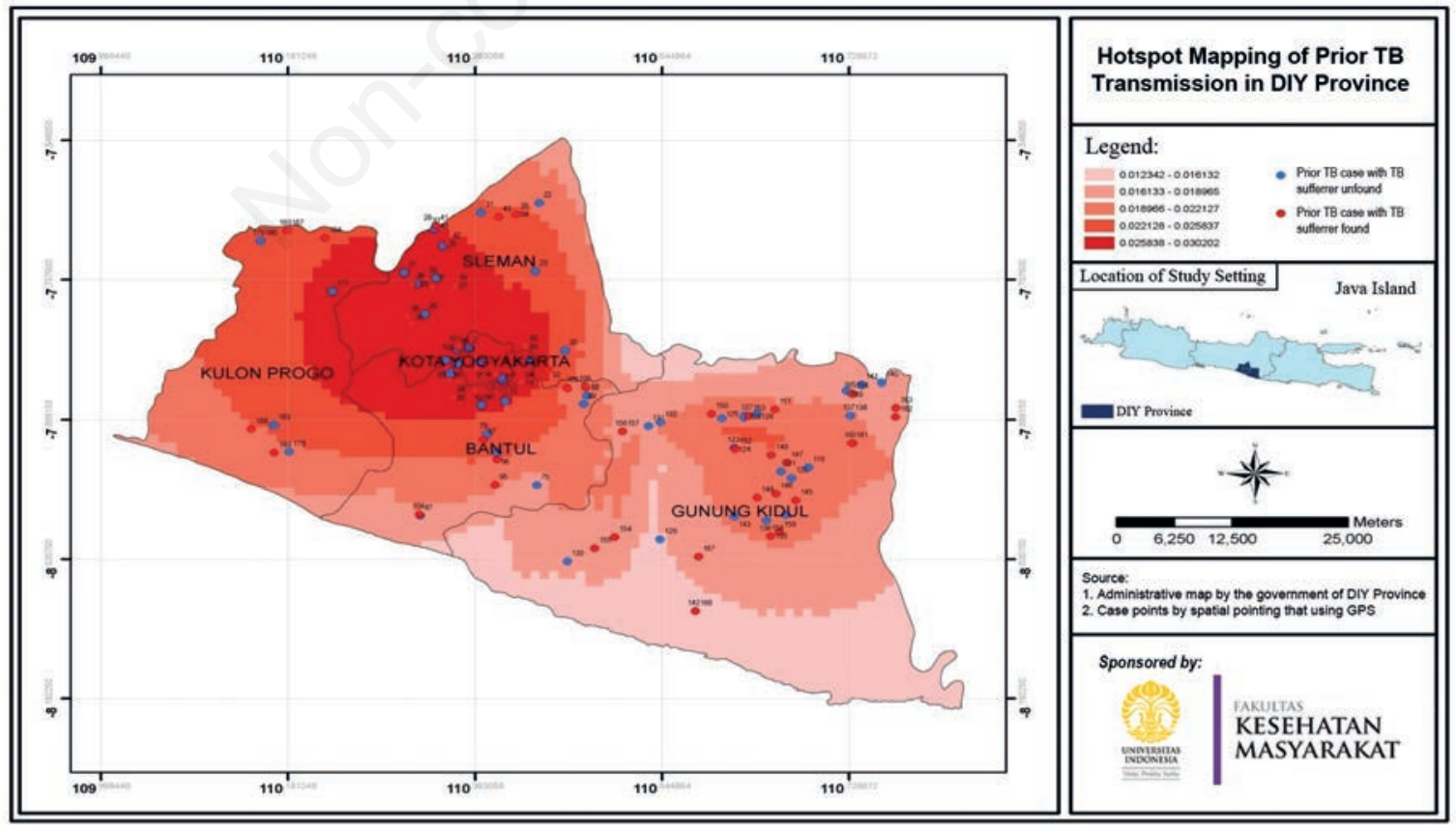

Figure 4. Hotspot mapping of tuberculosis (TB) cases in Daerah Istimewa Yogyakarta (DIY) Province, Indonesia. 
urban and suburban areas that had denser populations than other communities, such as residential areas along the industrial sites, urban areas, and new settlements with close proximity to others. Several studies found similar outcomes, i.e. that densely populated suburban and residential areas constitute neighbourhoods where TB is not only located but also concentrated (Asyary et al., 2017a).

The SDE analysis showed that the current TB case dispersion occurred within an ellipse with its centre at Kasihan District in Bantul Regency. This could be explained by prior TB cases in Kasihan District infecting others who dispersed along the ellipse as it represents a graph of how people move in the DIY Province. Kasihan District, located north of Bantul Regency, had a shorter distance to population centres in Yogyakarta City and Sleman Regency. Furthermore, the ease of access to the centres of cities in DIY Province indicates a higher probability of social traffic and leads to local transmission, as there is a high likelihood of social interaction. It has been shown in the other similar settings that local transmission enables TB transmission amongst neighbourhoods in suburban communities (Oren et al., 2014; Yadav et al., 2014; Noppert et al., 2017).

An increase of TB cases in the future is likely in all of Yogyakarta City, as well as in half of Sleman Regency's territory. Kernel estimation showed the highest risk of TB cases that could be transmitted into these densely populated residential areas in the next period of transmission. TB is an established disease whose transmission patterns are well-known and it commonly affects neighbouring populations in this way (Zhang et al., 2011). Additionally, one should be aware that low education, unemployment and low economic status, likely in crowded settlements, often go together with aggregation of TB (Kartasasmita, 2009; Lonnroth et al., 2009; Metcalfe et al., 2010; Hargreaves et al., 2011).

In this study, spatial analysis not only revealed the distribution of the existing TB burden but also provided a forecast based on transmission patterns that could be utilized to prevent the TB burden in the future. Although spatial analysis with respect to health was applied as an approach separate from other tools used when establishing support for policy decisions, different studies have begun to predict what will happen next (Feske et al., 2011; Ansariadi and Manderson, 2015; (Asyary et al., 2017b). In the US, spatial description contributed effectively to TB elimination by predicting its endemic settings based on known determinants (Feske et al., 2011).

The global effort to cure adult TB using the DOTS strategy has been evaluated with successful implementation in order to treat TB in both industrial and developing countries (Paramasivan et al., 2010). Implementation of the DOTS strategy has enabled TB patients to be observed by health workers, community volunteers or family member when taking their prescribed medication, even for consuming daily TB drugs for at least six months as needed (WHO, 2006). This approach is naturally likely to improve adherence and mitigate the severity of the disease for the individual patient. However, it does not help in finding the transmission source as infected people will not be discovered if they do not apply for medical support, and they might not do so unless severely ill (Karumbi and Garner, 2015; Asyary, 2017). In addition, developing countries such as Indonesia still face a major problem of treatment adherence for intensive TB therapy, as patients do not always accept long treatment periods, neither the two weeks of active bacillus culture conversion nor the six months of overall treatment (Lonnroth et al., 2009; Ismail and Bulgiba, 2013). In this country, especially DIY Province, there is a barrier to interrupt transmission as people live close to each other, especially with respect to vulnerable family members, such as children who are at high risk (National Data and Information Center, 2013). With low complacency and limited provision of means to break transmission, e.g., through active case detection and follow-up of contacts, the risk of infection remains high. This study lacks TB modelling, currently using a space-time permutation model in order to describe the TB clustering, which enables the evaluation of TB cases' concentration with one, two, or more TB clusters among the population.

\section{Conclusions}

Suburban communities in close connection with densely populated residential areas are more likely to acquire TB, currently or in the future. This emphasizes the need for investigating the pattern of TB transmission, which is best done by spatial statistics as it can reveal aggregation of cases and help predict density dispersions. This type of analysis is essential not only for TB control and management but also for other health problems related to environmental factors. Further study is needed, with the prospect of applying more precise and accurate measurements of key variables to prepare a better public policy.

\section{References}

Alene KA, Viney K, McBryde ES, Clements ACA, 2017. Spatiotemporal transmission and socio-climatic factors related to paediatric tuberculosis in north-western Ethiopia. Geospat Health 12:342-50.

Ansariadi A, Manderson L, 2015. Antenatal care and women's birthing decisions in an Indonesian setting: Does location matter? Rural Remote Health 15:1-17.

Asyary A, 2017. Childhood tuberculosis: a neglected paradigm in developing countries. Public Health Indonesia 3:7-10.

Asyary A, Eryando T, Purwantyastuti P, Junadi P, Clark C, Teijlingen EV, 2017a. Level of exposure of childhood tuberculosis with adult pulmonary tuberculosis household contacts. Kesmas: Nation Public Health J 12:1-6.

Asyary A, Purwantyastuti P, Eryando T, Junadi P, 2017b. Perceived of healthcare utilization by adult pulmonary tuberculosis patients for their children in Yogyakarta. Asian J Epidemiol 10:70-5.

BPS-DIY, 2014. [Daerah Istimewa Yogyakarta dalam Angka]. Yogyakarta: Balai Pusat Statistik Provinsi DIY, Indonesia. Available from: https://yogyakarta.bps.go.id/publication/ 2014/11/27/45a3ec0d044f535fc50a0992/daerah-istimewayogyakarta-dalam-angka-2014.html

Cranmer K, 2001. Kernel estimation in high-energy physics. Comput Phys Commun 136:198-207.

Feske ML, Teeter LD, Musser JM, Graviss EA, 2011. Including the third dimension: A spatial analysis of TB cases in Houston Harris County. Tuberculosis 91:S24-33.

Giyarsih SR, 2010. Urban sprawl of the city of Yogyakarta, special reference to the stage of spatial transformation (case study at Maguwoharjo Village, Sleman District). Indon J Geogr 42:49-60.

Hargreaves JR, Boccia D, Evans CA, Adato M, Petticrew M, Porter JD, 2011. The social determinants of tuberculosis: from evidence to action. Am J Public Health 101:654-62. 
Ismail I, Bulgiba A, 2013. Determinants of unsuccessful tuberculosis treatment outcomes in Malaysian HIV-infected patients. Prev Med 57:S27-30.

Jacob BJ, Krapp F, Ponce M, Gottuzzo E, Griffith DA, Novak RJ, 2010. Accounting for autocorrelation in multi-drug resistant tuberculosis predictors using a set of parsimonious orthogonal eigenvectors aggregated in geographic space. Geospat Health 4:201-17.

Kang SY, Cramb SM, White NM, Ball SJ, Mengersen KL, 2016. Making the most of spatial information in health: a tutorial in Bayesian disease mapping for areal data. Geospat Health 11:190-8.

Kartasasmita CB, 2009. [Epidemiologi Tuberkulosis]. Sari Pediatr 11:124-9.

Karumbi J, Garner P, 2015. Directly observed therapy for treating tuberculosis. Cochrane Database Syst Rev 5:CD003343.

Khan AA, 1986. Two simple methods of spatial analysis and their applications in location-oriented health services research. Am J Public Health 76:1207-9.

Lai PC, So FM, Chan KW, 2009. Spatial epidemiological approaches in disease mapping and analysis. CRC Press Taylor \& Francis, New York, NY.

Lefever DW, 1926. Measuring geographic concentration by means of the standard deviational ellipse. Am J Sociol 32:88-94.

Lin H, Shin S, Blaya JA, Zhang Z, Cegielski P, Contreras C, Asencios L, Bonilla C, Bayona J, Paciorek CJ, Cohen T, 2011. Assessing spatiotemporal patterns of multidrug-resistant and drug-sensitive tuberculosis in a South American setting. Epidemiol Infect 139:1784-93.

Lonnroth K, Jaramillo E, Williams BG, Dye C, Raviglione M, 2009. Drivers of tuberculosis epidemics: the role of risk factors and social determinants. Soc Sci Med 68:2240-6.

Metcalfe JZ, Kim EY, Lin SYG, Cattamanchi A, Oh P, Flood J, Hopewell PC, Kato-Maeda M, 2010. Determinants of multidrug-resistant tuberculosis clusters, California, USA, 20042007. Emerg Infect Dis 16:1403-9.

National Data and Information Center, 2013. [Ringkasan Eksekutif Data dan Informasi Kesehatan Provinsi DIY] Executive summary of health's data and information of DIY Province. Pusat Data dan Informasi Kementerian Kesehatan Republik Indonesia, Jakarta, Indonesia.

Noppert GA, Yang Z, Clarke P, Ye W, Davidson P, Wilson ML, 2017. Individual- and neighborhood-level contextual factors are associated with Mycobacterium tuberculosis transmission: genotypic clustering of cases in Michigan, 2004-2012. Ann Epidemiol 27:371-6.e5.

Oren E, Narita M, Nolan C, Mayer J, 2014. Neighborhood socioe- conomic position and tuberculosis transmission: a retrospective cohort study. BMC Infect Dis 14:227.

Paneth N, 2004. Assessing the contributions of John Snow to epidemiology: 150 years after removal of the broad street pump handle. Epidemiology 15:514-6.

Paramasivan CN, Lee E, Kao K, Mareka M, Kubendiran G, Kumar T, Keshavjee S, Satti H, Alabi G, Raviglione M, Roscigno G, 2010. Experience establishing tuberculosis laboratory capacity in a developing country setting. Int J Tuberc Lung Dis 14:5964.

Raviglione MC, Snider DE, Kochi A, 1995. Global epidemiology of tuberculosis. JAMA 273:220-6.

Rollemberg CV, Silva MM, Rollemberg KC, Amorim FR, Lessa NM, Santos MD, Souza AM, Melo EV, Almeida RP, Silva AM, Werneck GL, Santos MA, Almeida JA, Jesus AR, 2015. Predicting frequency distribution and influence of sociodemographic and behavioral risk factors of Schistosoma mansoni infection and analysis of co-infection with intestinal parasites. Geospat Health 10:13-9.

Smithies M, 1986. Yogyakarta: cultural heart of Indonesia. Oxford University Press, Singapore.

Terlikbayeva A, Hermosilla S, Galea S, Schluger N, Yegeubayeva S, Abildayev T, Muminov T, Akiyanova F, Bartkowiak L, Zhumadilov Z, Sharman A, El-Bassel N, 2012. Tuberculosis in Kazakhstan: analysis of risk determinants in national surveillance data. BMC Infect Dis 12:1-9.

World Health Organization (WHO), 2006. Stop TB partnership. The Stop TB Strategy: Building on and enhancing DOTS to meet the TB-related Millenium Development Goals. World Health Organization, Geneva, Switzerland.

Yadav RP, Nishikiori N, Satha P, Eang MT, Lubell Y, 2014. Costeffectiveness of a tuberculosis active case finding program targeting household and neighborhood contacts in Cambodia. Am J Trop Med Hyg 90:866-72.

Yuill RS, 1971. The standard deviational ellipse; an updated tool for spatial description. Geografiska Annaler: Ser B, Human Geogr 53:28-39.

Zendejas-Martinez H, Townsend Peterson A, Milian-Suazo F, 2008. Coarse-scale spatial and ecological analysis of tuberculosis in cattle: an investigation in Jalisco, Mexico. Geospat Health 3:29-38.

Zhang X, Wei X, Zou G, Walley J, Zhang H, Guo X, Zhu L, Liu Z, 2011. Evaluation of active tuberculosis case finding through symptom screening and sputum microscopy of close contacts in Shandong, China. Trop Med Int Health 16:1511-7. 